\title{
Bacteriological quality of packaged ice cream in Gaza city, Palestine
}

\author{
Emad Abou-El Khair, ", Abd Al- Raziq Salama ${ }^{2}$, Hamdan Radwan ${ }^{2}$, Abdelrahman Khalafallah ${ }^{3}$, \\ Hashem Arafa ${ }^{4}$ \\ ${ }^{1}$ Department of Biology, Faculty of Science, Al-Azhar University- Gaza, Palestine \\ ${ }^{2}$ Department of Food Science \& Technology, Faculty of Agriculture, Al-Azhar University- Gaza, Palestine \\ ${ }^{3}$ Department of Food \& Technology, Faculty of Agriculture, Cairo University, Egypt \\ ${ }^{4}$ Department of Public Health, Ministry of Health, Gaza, Palestine
}

Email address:

e.khahir@alazhar.edu.ps (E. Abou-El Khair), eabouelkhair@gmail.com (E. Abou-El Khair)

\section{To cite this article:}

Emad Abou-El Khair, Abd Al- Raziq Salama, Hamdan Radwan, Abdelrahman Khalafallah, Hashem Arafa. Bacteriological Quality of Packaged Ice Cream in Gaza City, Palestine. Journal of Food and Nutrition Sciences. Vol. 2, No. 3, 2014, pp. 68-73.

doi: $10.11648 /$ j.jfns.20140203.14

\begin{abstract}
Ice cream is absolutely one of the most popular and favorite food product for Palestinian children and adults. However, it is one of the most favorable foods for bacterial growth and potential source of food poisoning. The main objective of this work was to determine the bacteriological quality of packaged ice cream sold in Gaza city. One hundred samples of traditional sealed packaged ice cream were collected randomly from 20 different food stores of Gaza city. The samples represented all types of ice cream products in the local markets; they included chocolate, fruits, nuts and fruits flavor types. Bacteriological quality was assessed through the examination of collected ice cream samples for total aerobic count, coliform and fecal coliform, Salmonella spp., Shigella spp., Staphylococcus aureus, Klebsiella pneumoniae, Enterobacter sakazakii, Escherichia coli, Listeria ivanovii and L. grayi. Results revealed that many ice cream samples were contaminated with coliform, fecal coliform, E. coli, S. aureus, K. pneumoniae, E. sakazakii, L. grayi and L. ivanovii. Repeated electricity shuts for long periods in addition to poor handling of such perishable products may be the cause of their contamination. It is recommended to launch awareness programs to minimize the contamination of ice cream products.
\end{abstract}

Keywords: Bacterial Contamination, Gaza City, Packaged Ice Cream

\section{Introduction}

Ice cream is a nutritionally enriched dairy product which is produced by freezing pasteurized mixture of milk solids. Ice cream is rich in fat, sugar, emulsifier and stabilizer. Flavor enrichment of ice cream is an optional addition of fruits nuts, candies, syrups and other flavoring ingredients (1).

Ice cream should contain extremely low bacterial load, but higher bacterial counts have been reported by many researchers. This could be due to improper pasteurization process or post-process contamination (2).

Bacterial contamination is the main danger posed by old ice cream. Foods spoiled by bacteria which may look, smell and taste just fine can make us sick. Bacteria thrive in protein-rich foods that are also full of water including eggs, meat, fish and milk products. Freezing ice-cream and other frozen dairy products slow bacterial growth but doesn't kill the bacteria, which begin to grow again as food thaws. The risk of food-borne illness increases after ice cream has been opened and used. Some researchers recommended to discard any ice cream that thaws completely, due to the danger of bacterial growth (3).

There is limited information in Gaza strip about the risk of frequent electricity shutting in Gaza city which leads to several harmful events such as temperature abuse during ice cream packaging; which is considered as the main cause in the activation of pathogenic bacteria. Therefore, eating of ice cream can be a risk factor for tonsillitis and gastrointestinal tract infections such as diarrhea.

The aim of this study was to evaluate the bacteriological quality of sealed packaged ice cream in Gaza city.

\section{Materials and Methods}

This descriptive study was conducted to determine the 
bacteriological quality of packaged ice cream sold in Gaza city. Different tools were used to determine the total aerobic count and to isolate, purify and identify the pathogenic bacteria that may contaminate ice cream.

\subsection{Ice Cream Samples Collection}

During the study period (June to August 2012), 100 samples, twenty five from each type (chocolate, fruits flavor, fruits and nuts) were collected from different local food stores of Gaza city.

A sample unit consisted of a minimum of $100 \mathrm{~g}$ ice cream. The samples were collected in $200 \mathrm{ml}$ capacity clean sterile cups and transported to the laboratory in an ice box within 1 hour. The samples were examined as soon as they reached the laboratory or they were frozen at $-18^{\circ} \mathrm{C}$ till analysis.

\subsection{Bacteriological Analysis}

All the bacteriological media used throughout this study were purchased from $\mathrm{Hi}$ media company, India. The procedures followed for the detection of different bacteriological parameters; Total aerobic count, Coliform, Fecal coliform, Escherichia coli, E. coli O157: H7, Enterobacter sakazakii, Klebsiella pneumoniae, Staphylococcus aureus, Salmonella spp., Shigella spp , Listeria ivanovii and $L$. grayi were as described in the standard methods for examination of water and waste water (4).

\subsubsection{Biochemical Tests}

The Analytical Profile Index (API) 20 E and Staphylococcus API strips (Bio Merieux, France) were used as the biochemical systems for identification.

Data analysis was performed using SPSS, version 18.0 computer software.

\section{Results}

\subsection{Bacteriological Analysis of Ice Cream Samples}

The bacteriological analysis of ice cream showed that most samples do not complied (failed) the Palestinian standards for ice cream. Regarding the total aerobic count, 51 samples (51\%) do not complied the Palestinian standard (more than $2.5 \times 10^{5}$ ). Coliform represented the highest level of contamination (56\%) while all samples were free from salmonella spp. and Shigella spp. (Table 1).

Table 1. Presence of different types of bacteria in ice cream samples.

\begin{tabular}{lcccc}
\hline \multirow{2}{*}{$\begin{array}{l}\text { Type of } \\
\text { Bacteria }\end{array}$} & \multicolumn{2}{c}{ Positive samples } & \multicolumn{2}{c}{ Negative samples } \\
\cline { 2 - 5 } & Number & percentage & number & percentage \\
\hline Total aerobic & 51 & 51 & 49 & 49 \\
count & 23 & 23 & 77 & 77 \\
Staph. aureus & 56 & 56 & 44 & 44 \\
Coliform & 46 & 46 & 54 & 54 \\
Fecal & 44 & 44 & 56 & 56 \\
coliform & & & & \\
E. coli & & & & \\
\hline
\end{tabular}

\begin{tabular}{lcccc}
\hline \multirow{2}{*}{$\begin{array}{l}\text { Type of } \\
\text { Bacteria }\end{array}$} & \multicolumn{2}{c}{ Positive samples } & \multicolumn{2}{c}{ Negative samples } \\
\cline { 2 - 5 } & Number & percentage & number & percentage \\
\hline E. coli O 157: & 1 & 1 & 99 & 99 \\
H 7 & 36 & 36 & 64 & 64 \\
$\begin{array}{l}\text { K. pneumonia } \\
\text { Salmonella }\end{array}$ & 0 & 0 & 100 & 100 \\
spp. & 0 & 0 & 100 & 100 \\
$\begin{array}{l}\text { Shigella } \text { spp. } \\
\text { Enterob. }\end{array}$ & 8 & 8 & 92 & 92 \\
$\begin{array}{l}\text { sakazakii } \\
\text { Listeria }\end{array}$ & 6 & 6 & 94 & 94 \\
$\begin{array}{l}\text { ivanovii } \\
\text { Listeria grayi }\end{array}$ & 3 & 3 & 97 & 97 \\
\hline
\end{tabular}

\subsection{Distribution of Staphylococcus Aureus among Different Types of Ice Cream}

Table 2 shows that all chocolate and nuts ice cream samples were free from Staphylococcus aureus contamination, while fruits flavor ice-cream were highly contaminated $(68 \%)$.

Table 2. Distribution of Staphylococcus aureus among different types of ice cream.

\begin{tabular}{lcccc}
\hline Type of ice cream & $\begin{array}{c}\text { Positive } \\
\%\end{array}$ & $\begin{array}{c}\text { Negative } \\
\%\end{array}$ & Total & $\begin{array}{c}\boldsymbol{P} \\
\text { value }\end{array}$ \\
\hline chocolate ice cream & $0(0)$ & $25(100)$ & $25(25)$ & \\
Fruits flavor ice & $17(68)$ & $8(32)$ & $25(25)$ & \\
cream & $6(24)$ & $19(76)$ & $25(25)$ & 0.000 \\
Ice cream with fruits & $0(0)$ & $25(100)$ & $25(25)$ & \\
Ice cream with nuts & $23(23)$ & $77(77)$ & $100(100)$ & \\
Total & & & \\
\hline
\end{tabular}

\subsection{Distribution of Coliform among Different Types of Ice Cream}

In the term of contamination with coliform, the ice cream with fruits presented $100 \%$ contamination with coliform, the chocolate and nuts presented the same level of infection (56\%) while ice cream with fruits flavor presented the lowest level of coliform infection (12\%) as shown in table 3 .

Table 3. Distribution of coliform among Different types of ice cream.

\begin{tabular}{lcccc}
\hline $\begin{array}{l}\text { Type of ice } \\
\text { cream }\end{array}$ & Positive\% & Negative\% & Total & P value \\
\hline $\begin{array}{l}\text { chocolate ice } \\
\text { cream }\end{array}$ & $14(56)$ & $11(44)$ & $25(25)$ & \\
$\begin{array}{l}\text { Fruits flavor ice } \\
\text { cream }\end{array}$ & $3(12)$ & $22(88)$ & $25(25)$ & \\
$\begin{array}{l}\text { Ice cream with } \\
\text { fruits }\end{array}$ & $25(100)$ & $0(0)$ & $25(25)$ & 0.000 \\
$\begin{array}{l}\text { Ice cream with } \\
\text { nuts }\end{array}$ & $14(56)$ & $11(44)$ & $25(25)$ & \\
Total & $56(56)$ & $44(44)$ & $100(100)$ & \\
\hline
\end{tabular}

\subsection{Distribution of E. coli among Different Types of Ice Cream}

Table 4 shows the effect of $E$. coli on different types of ice cream, the study showed that highest levels of $E$. coli infection present on ice cream with fruits $96 \%$ while the lowest with nuts $12 \%$. 
Table 4. Distribution of E. coli among Different types of ice cream.

\begin{tabular}{lcccc}
\hline $\begin{array}{l}\text { Type of ice } \\
\text { cream }\end{array}$ & Positive\% & Negative\% & Total & P value \\
\hline $\begin{array}{l}\text { chocolate ice } \\
\text { cream }\end{array}$ & $10(40)$ & $15(60)$ & $25(25)$ & \\
$\begin{array}{l}\text { Fruits flavor ice } \\
\text { cream }\end{array}$ & $7(28)$ & $18(72)$ & $25(25)$ & \\
$\begin{array}{l}\text { Ice cream with } \\
\text { ruits }\end{array}$ & $24(96)$ & $1(4)$ & $25(25)$ & 0.000 \\
$\begin{array}{l}\text { Ice cream with } \\
\text { nuts }\end{array}$ & $3(12)$ & $22(88)$ & $25(25)$ & \\
Total & $44(44)$ & $56(45)$ & $100(100)$ & \\
\hline
\end{tabular}

\subsection{Distribution of E. Coli O157: H7 among Different Types of Ice Cream}

Regarding to E. coli O157: H7, table 5 shows that 3 types of ice creams were free (chocolate, fruits and nuts), while fruits flavor presented $4 \%$.

Table 5.Distribution of E. coli O157: H7 among Different types of ice cream.

\begin{tabular}{lcccc}
\hline Type of ice cream & $\begin{array}{c}\text { Positive } \\
\mathbf{\%}\end{array}$ & $\begin{array}{c}\text { Negative } \\
\mathbf{\%}\end{array}$ & Total & P value \\
\hline $\begin{array}{l}\text { chocolate ice cream } \\
\text { Fruits flavor ice }\end{array}$ & $0(0)$ & $25(100)$ & $25(25)$ & \\
cream & $1(4)$ & $24(96)$ & $25(25)$ & \\
Ice cream with fruits & $0(0)$ & $25(100)$ & $25(25)$ & 0.38 \\
Ice cream with nuts & $0(0)$ & $25(100)$ & $25(25)$ & \\
Total & $1(1)$ & $99(99)$ & $100(100)$ & \\
\hline
\end{tabular}

\subsection{Distribution of K. pneumoniae among Different Types of Ice-Cream}

In the term of presence of $K$. pneumonia among different types of ice cream, it is observed that fruits type had the maximum level of contamination $68 \%$, while fruits favor and nuts had the lower value $16 \%$ (Table 6).

Table 6. Distribution of K. pneumoniae among Different types of ice cream.

\begin{tabular}{lcccc}
\hline Type of ice-cream & Positive\% & Negative\% & Total & $\begin{array}{c}\boldsymbol{P} \\
\text { value }\end{array}$ \\
\hline $\begin{array}{l}\text { chocolate ice cream } \\
\text { Fruits flavor ice }\end{array}$ & $11(44)$ & $14(56)$ & $25(25)$ & \\
$\begin{array}{l}\text { cream } \\
\text { Ice cream with }\end{array}$ & $4(16)$ & $21(84)$ & $25(25)$ & \\
$\begin{array}{l}\text { fruits } \\
\text { Ice cream with nuts }\end{array}$ & $4(16)$ & $21(84)$ & $25(25)$ & \\
Total & $36(36)$ & $64(64)$ & $\begin{array}{c}100 \\
(100)\end{array}$ & \\
\hline
\end{tabular}

\subsection{Distribution of Enterobacter Sakazakii among Different Types of Ice Cream}

The contamination of Enterobacter sakazakii was observed in all types of ice cream, $16 \%$ in fruits flavor as maximum percentage of infection and $4 \%$ for chocolate and fruits types as the minimum infection level. Meanwhile in ice cream with nuts analysis, only two samples were contaminated with Enterobacter sakazakii (Table 7).
Table 7. Distribution of Enterobacter sakazakii among Different types of ice cream.

\begin{tabular}{lcccc}
\hline $\begin{array}{l}\text { Type of ice } \\
\text { cream }\end{array}$ & Positive $\%$ & Negative\% & Total & P value \\
\hline $\begin{array}{l}\text { chocolate ice } \\
\text { cream }\end{array}$ & $1(4)$ & $24(96)$ & $25(25)$ & \\
$\begin{array}{l}\text { Fruits flavor ice } \\
\text { cream }\end{array}$ & $4(16)$ & $21(84)$ & $25(25)$ & \\
$\begin{array}{l}\text { Ice cream with } \\
\text { fruits }\end{array}$ & $1(4)$ & $24(96)$ & $25(25)$ & 0.35 \\
$\begin{array}{l}\text { Ice cream with } \\
\text { nuts }\end{array}$ & $2(8)$ & $23(92)$ & $25(25)$ & \\
\begin{tabular}{l} 
Total \\
\hline
\end{tabular} & $8(8)$ & $92(92)$ & 100 & $(100)$ \\
\hline
\end{tabular}

\subsection{Distribution of Fecal Coliform among Different Types of Ice Cream}

Contamination with fecal coliform appeared clearly in fruits type of ice cream (88\%), 44\% in fruits flavor, and $36 \%$ in chocolate ice cream, while the lowest level of contamination $(16 \%)$ presented in ice cream with nuts ( Table 8).

Table 8. Distribution of fecal coliform among Different types of ice cream.

\begin{tabular}{lcccc}
\hline Type of ice cream & $\begin{array}{c}\text { Positive } \\
\%\end{array}$ & $\begin{array}{c}\text { Negative } \\
\%\end{array}$ & Total & P value \\
\hline chocolate ice cream & $9(36)$ & $16(64)$ & $25(25)$ & \\
Fruits flavor ice & $11(44)$ & $14(56)$ & $25(25)$ & \\
cream & $22(88)$ & $3(12)$ & $25(25)$ & 0.000 \\
Ice cream with fruits & $4(16)$ & $21(84)$ & $25(25)$ & \\
Ice cream with nuts & $46(46)$ & $54(54)$ & $100(100)$ & \\
Total & & & \\
\hline
\end{tabular}

\subsection{Distribution of Listeria Ivanovii among Different Types of Ice Cream}

Regarding to Listeria ivanovii, table 9 shows that ice cream with fruits flavor type were free of contamination, while other types presented light level of contamination $12 \%$ for chocolate, $8 \%$ for fruits and $4 \%$ for ice cream with nuts.

Table 9. Distribution of Listeria ivanovii among Different types of ice cream.

\begin{tabular}{lcccc}
\hline Type of ice-cream & $\begin{array}{c}\text { Positive } \\
\text { \% }\end{array}$ & $\begin{array}{c}\text { Negativ } \\
\mathbf{e} \%\end{array}$ & Total & $\begin{array}{c}\boldsymbol{P} \\
\text { value }\end{array}$ \\
\hline chocolate ice cream & $3(12)$ & $22(88)$ & $25(25)$ & \\
Fruits flavor ice cream & $0(0)$ & $25(100)$ & $25(25)$ & \\
Ice cream with fruits & $2(8)$ & $23(92)$ & $25(25)$ & 0.31 \\
Ice cream with nuts & $1(4)$ & $24(96)$ & $25(25)$ & \\
Total & $6(6)$ & $94(94)$ & $100(100)$ & \\
\hline
\end{tabular}

\subsection{Distribution of Listeria grayi among Different Types of Ice Cream}

Other type of Listeria was tested L. grayi, the results showed that two ice cream types were free of contamination, fruits flavor and fruits, while nuts presented $8 \%$ and chocolate was the lowest one $4 \%$ (Table 10 ). 
Table 10. Distribution of Listeria grayi among Different types of ice cream.

\begin{tabular}{lcccc}
\hline Type of ice cream & $\begin{array}{c}\text { Positive } \\
\mathbf{\%}\end{array}$ & $\begin{array}{c}\text { Negative } \\
\mathbf{\%}\end{array}$ & Total & P value \\
\hline chocolate ice cream & $1(4)$ & $24(96)$ & $25(25)$ & \\
Fruits flavor ice & $0(0)$ & $25(100)$ & $25(25)$ & \\
cream & $0(0)$ & $25(100)$ & $25(25)$ & 0.28 \\
Ice cream with fruits & $2(8)$ & $23(92)$ & $25(25)$ & \\
Ice cream with nuts & $3(3)$ & $97(97)$ & $100(100)$ & \\
Total & & &
\end{tabular}

\subsection{Distribution of all Types of Bacteria among Different Types of Ice-Cream}

From above mention, we observed that all ice cream types presented contamination with one or more type of bacteria, the following table presents the distribution of all types of bacteria among different types of ice cream, which appear that ice cream with fruits presented the maximum chance of contamination $80 \%$ then the chocolate ice cream $60 \%$ while fruits with flavor $52 \%$ and the low chance of contamination presented in ice cream with nuts.

Table 11. Distribution of All Types of Bacteria among Different types of ice cream.

\begin{tabular}{lcccc}
\hline Type of ice-cream & $\begin{array}{c}\text { Positive } \\
\%\end{array}$ & $\begin{array}{c}\text { Negative } \\
\%\end{array}$ & Total & $\begin{array}{c}\boldsymbol{P} \\
\text { value }\end{array}$ \\
\hline chocolate ice cream & $15(60)$ & $10(40)$ & $25(25)$ & \\
$\begin{array}{l}\text { Fruits flavor ice } \\
\text { cream }\end{array}$ & $13(52)$ & $12(48)$ & $25(25)$ & \\
Ice cream with fruits & $20(80)$ & $5(20)$ & $25(25)$ & 0.000 \\
Ice cream with nuts & $3(12)$ & $22(88)$ & $25(25)$ & \\
Total & $51(51)$ & $49(49)$ & $100(100)$ & \\
\hline
\end{tabular}

\subsection{Results of Salmonella and Shigella Species}

It is important to mention that all types of ice cream were free from salmonella spp. and Shigella spp..

\section{Discussion}

Frequent electricity shuts in Gaza city leads to temperature abuse during storage of ice cream, therefore, the main objective of this work was to determine the bacterial quality of ice cream sold in Gaza city.

In this study, the cross sectional method has been selected. Such method would be useful for the purpose of descriptive analysis being the most convenient and representative.

Most of the studies select approximately the same types of bacteria which can affect the ice cream, such as our types selected $(1,5,6)$. All ice cream samples contained one or more microorganism contamination, at the same times all samples were free from salmonella\& Shigella spp. The absence of Salmonella might be due to substituting a pasteurized egg product, egg substitute, or pasteurized shell eggs for the raw eggs in the favorite recipe. Egg products are eggs that have been removed from their shells and pasteurized, or another possibility that the ice cream made without using egg (7).

The possible source(s) of these bacteria in ice-cream could be from nose where it is commonly found; hands, skin, and clothing of handlers (8). Coughing, talking and sneezing produce droplets which could settle on ice cream during transportation, storage and retailing (9).

The status of microbial quality of ice cream being sold in the northwest region of Iran was investigated, results showed that all analyzed traditional cacao ice cream samples $(n=30)$ showed positive growth $(7.52 \pm 0.25 \mathrm{log}$ $\mathrm{cfu} / \mathrm{g}$ ) on plate count agar indicating the presence of aerobic microorganisms (1). Our results are more or less in agreement with these results.

The results show that each chocolate ice cream and with nuts are free from $S$. aureus contamination, while ice cream with fruits flavor present the highest level of infection $68 \%$.This result is more or less similar to other studies which showed heavy contamination of notable bacteria $(E$. coli, Klebsiella, Proteus, Salmonella and Staphylococcus) which may indicate fecal contamination $(9,10,11)$.

Contamination with coliform bacteria was detected, the ice cream with fruits presents $100 \%$ contamination with coliform, while, the chocolate and nuts present the same level of contamination $56 \%$ while ice cream with fruits flavor showed the lowest level of coliform infection $12 \%$. Also in a study in Cameron reported that $71.3 \%$ of 300 ice cream samples were infected with fecal bacteria(12). Another study by Bialasiewicz and Rzadzinska in Lahestan, $12.3 \%$ of 195 samples were infected with fecal coliforms were observed (13). Also coliforms were found in 47 of the $49(95.9 \%)$ samples from Guadalajara and in 10 of the 49 (20.4\%) samples from Houston (14). In studies in Libya, India and Dakar respectively, coliforms in percentages of 6, 19 and 10.6 in ice cream samples were reported (15).

Regarding to the effect of $E$. coli on different types of ice-cream, the study showed that the highest levels of $E$. coli present on ice cream with fruits $(96 \%)$ while the lowest with nuts (12\%). Many studies showed a compatible results and reported that more than $40 \%$ of the ice cream samples $(\mathrm{n}=50)$, were contaminated with $E$. coli $(10,16,17)$.

Regarding E. coli O157: H7, the present study showed that 3 types of ice creams are free (chocolate, fruits and nuts), while fruits flavor present just $4 \%$. While, in one study-showed that there are certain parallels that exist between the potential sources of contamination between these Gram-negative pathogens and the control measures that could be taken to prevent or reduce the risk of contamination(1).

Contamination with fecal coliform appear clearly in fruits type of ice-cream $88 \%, 44 \%$ in fruits flavor, and $36 \%$ in chocolate ice cream, while the lowest level of contamination present in ice cream with nuts $16 \%$. This finding support the results of many researchers $(1,13)$, showed that more than $75 \%$ of fruits ice creams produce in Teheran's confectionaries and $94.7 \%$ produced in workshops were contaminated. Fecal coliforms were detected in $64(80 \%)$ samples, and $E$. coli was detected in $60(75 \%)$. It is recommended to use and implement immediate regulatory measures like good manufacturing 
practices as well as distribution and retail storage practices for ensuring microbiological safety of ice cream (18).

Regarding to the presence of $K$. pneumoniae among different types of ice cream, we observed that fruits type have the maximum level of $K$. pneumoniae $(68 \%)$, while fruits flavor and nuts have the lower value (16\%). $K$. pneumoniae was not present in ice cream and kulfi samples whereas 60 and $70 \%$ samples of color ice bar and mango shake were positive for this organism, respectively (11).

The contamination with Enterobacter sakazakii was observed by the researcher in all types of ice cream, 16\% in fruits flavor as maximum percentage of contamination and $4 \%$ for chocolate and fruits types as the minimum infection level.

In the present study, the results showed that ice cream with fruits flavor type is free of contamination with Listeria ivanovii, while other types present light level of contamination $12 \%$ for chocolate, $8 \%$ for fruits and $4 \%$ for ice cream with nuts. Out of a total of 316 food samples analyzed, $103(32.6 \%)$ were positive for Listeria (20 from 43 in case of ice cream samples number(19).

Our results demonstrated that all types of ice cream are free from salmonella \& Shigella. In spite of using of Hazard Analysis Critical Control Points (HACCP) implementation to increase the microbiological quality of ice cream, the presence of salmonella still positive (20).

\section{Conclusion}

- $\quad$ Since ice cream harbors many potent pathogens, its microbial quality has always been crucially important to public health. Our results show that most of the ice cream samples failed to conform to the Palestinian standards.

\section{Recommendations}

- More interest in ice cream research is recommended to be practiced in food technology and health services.

- packaged ice cream must store at proper temperature, defrosted products must discarded and any melted ice cream must not re-freeze for sale.

- Hygienic practices during all preparation and handling processes should increase.

For consumers we can advise to purchase packaged ice cream products from freezer and to observe the hygienic conditions of the food stores.

\section{References}

[1] M. H. Movassagh, A. Movassagh, H. Mahmoodi, F. Servatkhahand M. R. Sourorbakhsh. "Microbiological contamination of the traditional chocolate ice-cream sold in the northwest region of Iran," Global Veterinaria, 2011,vol. 6 pp. $269-271$.
[2] L. Hoveyda, N.A. Mozafari, and H.F. Tehrani,"Determination of bacterial contamination different ice-creams in tehran," J. Med. Council I.R.I. Winter. 2006, vol. 23 pp. $383-390$.

[3] P.H. Schmutz, and E.H. Hoyle, "Safe handling of milk and dairy products, "Home and garden Information Center Clemson., 2007

[4] Standard Methods for the Examination of Water and Wastewater,20th Edn., American Public Health Association, American Water Works Association, Water Environment Federation., 1999.

[5] H. Yaman, M. Elmali, Z. Ulukanli, M. Tuzcu, and Genctave, K. "Microbial quality of ice-cream sold openly by retail outlets in Turkey. Rev. Med. Vet.2006, vol. 157 pp.457-462.

[6] A. H. Bartlet, and K. G.Hulten,"Staphylococcus aureus pathogenesis: Secretion systems, adhesins and invasins". Pediatr. Infect. Dis. J.2010 vol. 29 pp. 860-861

[7] U.S. Food and Drug Administration, Protecting and Promoting Your Health. http://www.fda.gov/Food/accessed at June 2013.

[8] B.C. Hobbs, and J. R. Golbert,"Food Poisoning and Food Hygiene." 4th Edn., Edward Arnold Limited, London., 1982,pp: 366.

[9] A. O. Ojokoh, "Microbiological examination of ice-cream sold in akure," Pak. J. Nutr.2006, vol. 5 pp. 536 -538.

[10] K. Ahmed, A. Hussain, Imran, M. A. Qazalbash, and W.Hussain," Microbiological quality of ice-cream sold in Gilgit town," Pak. J. Nutr., 2009 vol. 8 pp. 1397-1400.

[11] N. Yadav, P. Saini, D. Kaur, N. Srivastava, and D.Pandey," Microbial quality and safety of ready to serve street foods vended in Allahabad City, India," Internet J. Food Safety., 2011, vol.13 pp. 6-10.

[12] M. N. Wouafo, T. Njine, and R. Tailliez, "Hygiene and microbiologic quality of ice-creams produced in Cameroon. A public health problem," Bull. Soc. Pathol. Exot., 1996, vol.89 pp. 358-362.

[13] J. Afshin, and S. Saeid, "Fecal coliforms and fecal streptococci contamination of traditional ice-cream in Tabriz," Am. Eurasian J. Agric. Environ. Sci., 2011, vol. 11, pp. $812-814$.

[14] M. Kacaniova, and L. Juhaniakova," Microorganisms in confectionery products, "J. Microbiol. Biotechnol. Food Sci., 2011, vol. 1, pp. $57-69$.

[15] N. El-ashaef, K. S. Ghenghesh,Y. S. Abognah, S. O. Gnan, and A.Rahouma," Bacteriological quality of ice-cream in Tripoli-Libya," Food Control., 2006, vol.17, pp. 637-641.

[16] C. P. Kodikara, and P. A. Silva, "survey of the hygienic quality of market foods in Kandy," J. Natn. Sci. Coun. Sri Lanka., 1983, vol.11, pp. 247-253.

[17] T. Masud, "Microbiological quality and public health significance of ice-cream," J. Pak. Med. Assoc., 1989, vol. 39 , pp. $102-104$.

[18] H. Bahareem, H. A. El-Shamy, W. M. Bakr, and N. F.Gomaa,"Bacteriological quality of some dairy products (kariesh cheese and ice-cream) in Alexandria," J. Egypt. Public Health Assoc., 2007, vol. 82, pp. 491 -510. 
[19] A. Molla, R. Yilma, and D. Alemayehu,"Listeria monocytogenes and other Listeria species in retail meat and milk products in Addis Ababa, Ethiopia," Ethiopia J. Health Dev., 2004, vol.8, pp. 208-212.
[20] E. N. Kokkinakis, G. A. Fragkiadakis, S. H. Ioakeimidi, I. B Giankoulof-and A. N. Kokkinaki,"Microbiological quality of ice-cream after HACCP implementation: A factory case study," Czech J. Food Sci., 2008, vol.26, pp. 383 -391. 